\title{
THE IMPACT OF TEAM EMPOWERMENT ON VIRTUAL TEAM PERFORMANCE: THE MODERATING ROLE OF FACE-TO-FACE INTERACTION
}

\author{
BRADLEY L. KIRKMAN \\ Georgia Institute of Technology \\ BENSON ROSEN \\ University of North Carolina at Chapel Hill \\ PAUL E. TESLUK \\ University of Maryland \\ CRISTINA B. GIBSON \\ University of California, Irvine
}

\begin{abstract}
We investigated the relationship between team empowerment and virtual team performance and the moderating role of the extent of face-to-face interaction using 35 sales and service virtual teams in a high-technology organization. Team empowerment was positively related to two independent assessments of virtual team performanceprocess improvement and customer satisfaction. Further, the number of face-to-face meetings moderated the relationship between team empowerment and process improvement: team empowerment was a stronger predictor for teams that met face-toface less, rather than more, frequently.
\end{abstract}

Advances in communication and information technology have created new opportunities for organizations to build and manage virtual teams. Virtual teams are defined as groups of employees with unique skills, situated in distant locations, whose members must collaborate using technology across space and time to accomplish important organizational tasks (Lipnack \& Stamps, 2000). While virtual teams play an important role in industry worldwide, most of the knowledge about them derives from practitioner articles (Cascio, 2000; Coutu, 1998; Kirkman, Rosen, Gibson, Tesluk, \& McPherson, 2002; Townsend, DeMarie, \& Hendrickson, 1998), popular books (Duarte \& Snyder, 2001; Haywood, 1998; Lipnack \& Stamps, 2000), case studies (Maznevski \& Chudoba, 2000), and theoretical work (Armstrong \& Cole, 1995; Bell \& Kozlowski, 2002; Furst, Blackburn, \& Rosen, 2001; Griffith \& Neale, 2001; Griffith, Sawyer, \& Neale, 2003). There are recent exceptions (see Gibson and Cohen's [2003] edited volume), including several empirical investigations (Jarvenpaa, Knoll, \& Leidner, 1998; Jarvenpaa \& Leidner, 1999; Montoya-Weiss, Massey, \& Song, 2001; Warkentin, Sayeed, \& Hightower, 1997). The latter studies, however, used students performing artificial tasks with unrealistic time limits. To understand what is required for virtual teams to be successful, studies examining ongoing virtual work teams performing meaningful, complex tasks in business organizations are now needed.

Previous research has shown that various team types (for instance, project, management, parallel, and work) have different performance drivers (Cohen \& Bailey, 1997). For example, while autonomy has been linked to performance in permanent work teams, this is not the case for project teams (Cohen \& Bailey, 1997). Accordingly, it would be unwise to assume that factors influencing colocated (that is, face-to-face) team effectiveness are valid for virtual teams (Potter \& Balthazard, 2002). Previous research has demonstrated a positive relationship between team empowerment and colocated team performance (Burpitt \& Bigoness, 1997; Hyatt \& Ruddy, 1997; Kirkman \& Rosen, 1999; Wellins, Byham, \& Wilson, 1991). To date, however, little attention has been paid to virtual team empowerment. Thus, our first objective was to determine whether or not team empowerment is related to virtual team performance. Our second objective was to examine the possible moderating effect of the extent of face-to-face interaction on the team empowerment-team performance relationship. In practice, virtual teams vary on amount of face-toface interaction, which can range from no physical interaction to monthly face-to-face team meetings 
(Lipnack \& Stamps, 2000; Townsend et al., 1998). Thus, we add to the emerging theoretical and empirical research on virtual teams by including the extent of face-to-face interaction, which we believe is an important contingency variable for virtual team performance.

\section{LITERATURE REVIEW AND HYPOTHESES}

Both the existing literature on colocated teams and the emerging theoretical work on virtual teams contain many potential predictors of virtual team performance. In view of our own observations and others' reports on the typical tasks virtual teams perform (Bell \& Kozlowski, 2002; King \& Majchzrak, 2003; Raven, 2003), we focus on team empowerment as a key emergent state important to virtual team performance (cf. Marks, Mathieu, \& Zaccaro, 2001). Although not all virtual teams perform highly complex tasks, most are knowledgebased teams charged with developing new products, improving organizational processes, or satisfying complex customer problems (Duarte \& Snyder, 2001; Lipnack \& Stamps, 2000; Townsend et al., 1998). For example, Eastman Kodak's virtual teams design new products (Lipnack \& Stamps, 1999); Hewlett Packard's virtual teams solve clients' computing problems (Geber, 1995); and Sun Microsystems' virtual teams generate new business models (Lipnack \& Stamps, 2000).

Organizations increasingly face high levels of dynamic, complex change and environmental uncertainty (Champy \& Nohria, 1997). Because virtual teams can rapidly respond to business globalization challenges (Kayworth \& Leidner, 2001; Maznevski \& Chudoba, 2000; Montoya-Weiss et al., 2001), their use is expanding exponentially (Kirkman et al., 2002). Dispersed members' proximity to customers, markets, and resources in their local contexts enhances innovation ability (Gluesing et al., 2003; Maznevski \& Athanassiou, 2003). Members can be inserted in and removed from teams quickly when customer needs or environmental demands change (Townsend et al., 1998). For these and other reasons explained below, we believe that team empowerment is a critical predictor of virtual team performance. However, the strength of the relationship between team empowerment and virtual team performance may depend on the degree to which team members experience face-to-face interaction-that is, on how virtual the teams really are. Figure 1 depicts our contingency model of virtual team performance.

\section{Team Empowerment Defined}

To date, empowerment has been conceptualized and empirically examined primarily at the individual level of analysis (Conger \& Kanungo, 1988; Ford \& Fottler, 1995; Koberg, Boss, Senjem, \& Goodman, 1999; Liden, Wayne, \& Sparrowe, 2000; Spreitzer, 1995, 1996; Spreitzer, Kizilos, \& Nason, 1997; Thomas \& Velthouse, 1990). A growing body of recent theoretical and empirical research also supports the positive effects of empowerment for colocated work teams (Burpitt \& Bigoness, 1997; Hyatt \& Ruddy, 1997; Kirkman \& Rosen, 1997, 1999; Wellins et al., 1991). Team empowerment is defined as increased task motivation that is due to team members' collective, positive assessments of their organizational tasks (Kirkman \& Rosen, 2000). Teams experience empowerment on four dimensions: potency, the collective belief of a team that it can be effective; meaningfulness, the extent to which team members feel an intrinsic caring for their tasks; autonomy, the degree to which team members be-

FIGURE 1

A Contingency Model of Virtual Team Performance

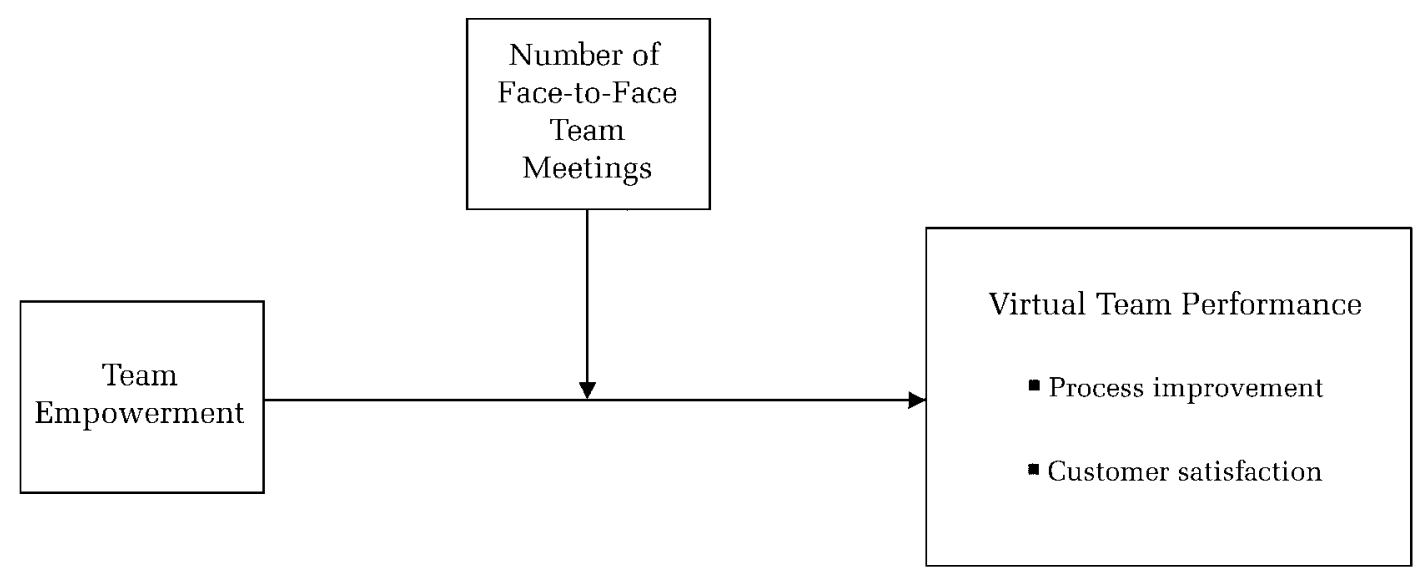


lieve that they have freedom to make decisions; and impact, the extent to which team members feel that their tasks make significant organizational contributions (Kirkman \& Rosen, 1997). The four dimensions combine additively to create an overall construct of team empowerment. Thus, even though a team may have little autonomy, members can still experience team empowerment to the extent that they feel a collective sense of potency, a high level of meaningfulness in the work, and a sense that the team's work has impact on stakeholders (cf. Spreitzer, 1995).

Team empowerment falls into the category of an emergent state, or a construct that characterizes "properties of the team that are typically dynamic in nature and vary as a function of team context, inputs, processes, and outcomes" (Marks et al., 2001: 357). Emergent states describe cognitive, motivational, and affective states of teams. Within the emergent state framework, team empowerment is a dynamic motivational construct. Whether members of a team feel empowered or not depends on their assessments of job and organizational characteristics. The degree to which team leaders allow them to make decisions is one such characteristic; whether or not the team has access to important resources is another (Kirkman \& Rosen, 1999). Unlike empowerment at the individual level, which consists of a set of individual cognitions (Spreitzer, 1995), team empowerment emerges from collective cognition-that is, it is socially constructed (Gibson, 2001)—and represents members' assessments of their tasks and the conditions under which their team works. Thus, the referent is the team rather than the individual (see Chan's [1998: 238-239] description of referent-shift consensus models). Team empowerment should not be confused with team processes such as communication or conflict, which involve the interdependent actions team members take to convert inputs to outcomes to achieve team goals (Marks et al., 2001). In contrast, team empowerment is a reflection of a team's motivation level at a given point in time.

Although the four-dimension conceptualization of both individual and team empowerment is relatively new (Kirkman \& Rosen, 1997; 1999; Spreitzer, 1995; Thomas \& Velthouse, 1990), each dimension has historical roots in previous theoretical models. For example, the team empowerment constructs of meaningfulness, autonomy, and impact grew out of three of the "critical psychological states" in the job characteristics model (Hackman \& Oldham, 1980); these are experienced meaningfulness of work, responsibility for the outcomes of work, and knowledge of the actual results of work activities, respectively. Potency and autonomy are analogous to competence and self-determination in Deci and Ryan's (1980) cognitive evaluation theory. What distinguishes team empowerment from earlier intrinsic motivation models is that team empowerment is conceptualized at the team, rather than the individual, level of analysis, and team empowerment combines dimensions that have been previously considered separate in earlier models.

\section{Team Empowerment and Virtual Team Performance}

In the absence of theoretical or empirical work examining empowerment in virtual teams, we argue that team empowerment may be more important to the performance of virtual teams than it is to the performance of colocated teams because of the unique nature of virtual team tasks. We believe that team empowerment will be especially critical for virtual team process improvement and customer satisfaction.

Process improvement. Because most virtual teams are knowledge-based teams that solve customer problems or develop new products, one of the most important performance outcomes is process improvement. Process improvement is analogous to team learning (Redding, 2000; Watkins \& Marsick, 1993), which is defined as "activities carried out by team members through which a team obtains and processes data that allow it to adapt and improve" (Edmondson, 1999: 351). Examples of process improvement behaviors include seeking feedback, discussing errors, and experimenting (Edmondson, Bohmer, \& Pisano, 2001).

The complex, knowledge-based tasks many virtual teams perform require behaviors such as planning and executing, integrating with other teams inside and outside organizational boundaries, managing team performance, improving team processes, and influencing organization-level direction and resource allocations (Mohrman, Cohen, \& Mohrman, 1995). Empowered teams have the authority to engage in these behaviors (Wellins et al., 1991). As a result, we believe, all four dimensions of team empowerment should contribute to virtual team process improvement. For example, higher team autonomy will likely lead to greater risk taking and experimentation (Tushman \& O'Reilly, 1996). Team members will not have to wait for managerial permission or guidance before engaging in risk-taking activities crucial to process improvement and learning, such as detecting environmental changes and proactively meeting changing customer needs (Edmondson, 1999). As Redding noted, "Teams that were trained to follow tradi- 
tional prescribed teamwork practices were less apt to produce novel, creative solutions than teams that were left to their own devices" (2000: 9).

Through potency, another dimension of team empowerment, virtual team members will likely behave proactively (Crant, 2000), seek continuous improvement, revise work processes, and search out innovative solutions to work problems (Hyatt \& Ruddy, 1997). All of these activities should be associated with higher levels of virtual team process improvement (Lipnack \& Stamps, 2000; Maznevski \& Chudoba, 2000; Townsend et al., 1998). Likewise, when empowered team members experience meaning in their work, they are more likely to respond with higher levels of persistence (cf. Gorn \& Kanungo, 1980) and motivation (Hackman \& Oldham, 1980). Persistence and motivation are likely to translate into higher levels of learning and process improvement (Edmondson, 2002). Similarly, when empowered team members experience impact, or knowledge of how their work affects others, they are more likely to have the information necessary to make accurate adjustments in their work (Kirkman \& Rosen, 1997). Impact allows teams to enhance learning by improving team members' collective understanding of a situation and revealing unexpected consequences of previous actions (Edmondson, 1999). Empowerment has been empirically linked to innovation at both the team (Burpitt \& Bigoness, 1997) and individual levels of analysis (Spreitzer, 1995). In summary, empowered virtual teams-those whose members experience high levels of autonomy, potency, meaningfulness, and impact-should be more capable of taking self-corrective actions to improve team processes than less empowered virtual teams. Thus, we predict:

Hypothesis 1. Team empowerment will be positively related to virtual team process improvement.

Team customer satisfaction. Another outcome vitally important to virtual teams is customer satisfaction (Duarte \& Snyder, 2001; Haywood, 1998; Lipnack \& Stamps, 2000). Since virtual teams increasingly span departmental boundaries or organizations, satisfying key internal and external customers is paramount to virtual team success. All four empowerment dimensions should enable virtual teams to better satisfy customers. For example, teams that experience high autonomy take responsibility to handle customer complaints directly and often self-diagnose quality problems and issues without waiting for managerial approval (Wellins et al., 1991). Indeed, preliminary research suggests that collective perceptions of team autonomy are critical if virtual teams are to quickly respond to customer requests or environmental changes (Townsend et al., 1998). More potent virtual team members believe they can deal with customer complaints and issues. Guzzo and his associates (Guzzo et al., 1991; Shea \& Guzzo, 1987) found that more potent colocated teams had higher levels of internal and external customer service. Virtual teams that find their tasks meaningful will likely take care and concern with customers because such responsibilities are intrinsically important (Hackman, 1987). Lastly, a sense of impact should allow team members to better know the exact changes needed to satisfy customers (Hackman \& Oldham, 1980). Support for this view comes from empirical research demonstrating that a related characteristic, team organizational awareness (that is, the extent to which team members understand how their behavior influences organizational success), is linked to customer satisfaction (Hyatt \& Ruddy, 1997). Further, empirical research in colocated teams has demonstrated that team empowerment is positively related to customer satisfaction (Kirkman \& Rosen, 1999). Given the nature of their tasks and the challenges of virtuality, we expect this relationship to be even stronger in virtual teams. Hence, we predict:

Hypothesis 2. Team empowerment will be positively related to virtual team customer satisfaction.

\section{The Moderating Impact of the Extent of Face-to- Face Interaction in Virtual Teams}

Even though most of the virtual teams literature is anecdotal or case-based, it has addressed two questions: (1) what are the key antecedents to virtual team performance and (2) how do virtual and colocated teams differ? To our knowledge, however, there has been little systematic analysis of these issues to date using intact virtual teams in industry. Further, the second question implies that teams can be viewed as completely virtual or completely face-to-face. Recently, scholars have argued that this distinction is unrealistic and artificial; instead, virtuality lies on a continuum ranging from highly to minimally virtual (Cohen \& Gibson, 2003; Griffith \& Neale, 2001; Griffith et al., 2003). For example, some teams that are referred to as colocated actually communicate electronically between face-to-face meetings. Similarly, teams that are viewed as virtual often have at least an initial face-to-face meeting (Geber, 1995), and many virtual teams, including globally dispersed teams, schedule periodic face-toface meetings (Geber, 1995; Maznevski \& Chudoba, 2000). 
Although some researchers have limited the term "virtual team" to teams that never meet face-to-face (Jarvenpaa et al., 1998; Kristof, Brown, Sims, \& Smith, 1995), many definitions acknowledge that virtual teamwork involves some level of face-toface interaction even though, on a day-to-day basis, most work is carried out using technology-mediated communication (Maznevski \& Chudoba, 2000). For example, Townsend and colleagues defined virtual teams as "groups of geographically and/or organizationally dispersed coworkers that are assembled using a combination of telecommunications and information technologies to accomplish an organizational task" (1998: 18). They go on to state, "Virtual teams rarely, if ever, meet in a face-to-face setting" (Townsend et al., 1998: 18). Bell and Kozlowski stated that "it is the absence of this proximal, face-to-face interaction between members of virtual teams that makes them 'virtual' and distinguishes them from more traditional teams" (2002: 22).

We acknowledge that virtuality is likely multidimensional (Cohen \& Gibson, 2003; Griffith \& Neale, 2001; Griffith et al., 2003; Townsend et al., 1998), encompassing, for example, the richness of the communication media used by members to accomplish tasks. A highly virtual team might communicate using only e-mail or facsimile, thus omitting all nonverbal communication such as facial expressions or tone of voice. In contrast, a less virtual team will likely meet face-to-face periodically and supplement this interaction with richer communication media, such as teleconferencing or Webbased videoconferences, and thus capturing many, but not all, of the subtleties of face-to-face teams. Other dimensions of virtuality could be the extent to which members are distributed across space (physical proximity; Griffith et al., 2003) and time (time zones; Cohen \& Gibson, 2003). A highly virtual team might have members who are spread throughout the world in different time zones, while a less virtual team might have members located in the same city and who are temporally entrained. Regardless of the alternate ways to conceptualize degree of virtuality, given the importance of faceto-face meetings in almost all virtual team definitions, we focus here on that specific element of virtuality. The extent to which virtual team members assemble for intact, face-to-face meetings is an important process factor that likely changes fundamental features of task accomplishment.

We believe an important research question is this: How does the degree of virtuality influence the relationship between virtual team antecedents and outcomes? Studies addressing this question might uncover important differences in virtual team leadership and support requirements that depend upon the extent of face-to-face interaction and might also generate important theoretical insights regarding virtual teams. As Bell and Kozlowski stated in their recent theoretical review of virtual teams, "There is little current theory to guide researchers on the leadership and management of virtual teams" (2002: 15). In our study, we chose to focus on degree of virtuality as a key moderator, rather than on other potential moderators, such as task interdependence or task complexity, because we believed that the extent of face-to-face interaction is one of the most important elements differentiating teams that interact primarily using technology (Cohen \& Gibson, 2003). In our contingency model of virtual team performance (see Figure 1), we argue that team empowerment will be a stronger predictor of virtual team performance the less frequently teams meet face-to-face.

Underlying our rationale that virtuality is an important moderator is the recognition that both intrinsic and extrinsic factors may motivate teams (Deci \& Ryan, 1980). Intrinsic motivation in teams consists of a variety of factors embedded in the task or activity itself. Thus, intrinsic motivation is inherent in team empowerment, which is rooted in assessments of a team's set of tasks, responsibilities, and capabilities (Kirkman \& Rosen, 1999). For example, team members are more likely to feel intrinsically motivated when they believe their team has the following: high performance capability (that is, potency), a strong sense of meaning generated by the team's work (meaningfulness), high responsibility and authority to carry out work (autonomy), and a full realization that the team's work has significant consequences for its organization (impact) (Kirkman \& Rosen, 1997).

In contrast, extrinsic motivation originates from factors outside the team and external to team members, such as rewards and evaluations, recognition from external team leaders, feedback received from organizational stakeholders and outside customers, and peer pressure or team norms (Deci \& Ryan, 1980; Hackman, 1987). These forms of extrinsic motivation are frequently encountered in teams that often meet face-to-face (that is, teams low in virtuality). However, highly virtual teams have physical, temporal, and psychological separation (Lipnack \& Stamps, 2000; Townsend et al., 1998), are less embedded in immediate contexts, and have members who are less connected to each other and their team leaders. Thus, many of the factors that typically function as extrinsic motivators in faceto-face teams are likely to be less powerful sources of motivation for teams that seldom meet face-toface. For instance, the dispersed nature of virtual 
teams makes direct supervision of team members through coaching and rewarding team performance less viable (Bell \& Kozlowski, 2002; Montoya-Weiss et al., 2001). The physical absence of a formal leader exacerbates lack of extrinsic motivation (Kayworth \& Leidner, 2001). In virtual teams that rarely meet face-to-face, team leaders often have no choice but to distribute and delegate leadership functions and responsibilities to team members (Bell \& Kozlowski, 2002). Virtual team members will more likely assume these responsibilities and functions if they feel highly empowered. In short, empowerment in a virtual team may function as a substitute for many of the leadership functions that are normally executed by a team leader who is physically present and interacting face-to-face with a team (Kerr \& Jermier, 1978). Given the probable lack of extrinsic motivators in highly virtual teams, intrinsic motivation through team empowerment likely becomes more critical for team performance. ${ }^{1}$

In addition, teams with few opportunities to meet face-to-face are highly vulnerable to process losses and performance problems (Gibson \& Cohen, 2003; Lipnack \& Stamps, 2000). One factor that might offset performance problems is team empowerment. When team members have a collective sense of potency, meaningfulness, autonomy, and impact, their individual and collective actions will likely be more proactive and decisive than those of the members of less empowered teams (Kirkman \& Rosen, 1999). In the absence of a strong sense of team empowerment, however, these virtual team dynamics may lead to distrust and information hoarding, unwillingness to take risks and learn from mistakes, and even inaction and paralysis. All of these problems detract from process improvement and customer service. Frequent meetings, particularly under the guidance of a skilled leader, should help virtual teams overcome these problems (Bell \& Kozlowski, 2002). Without such meetings, however, team empowerment will likely be critical if team members are to be confident and decisive, willing to experiment and learn from their mistakes, and less dependent on formal team leaders, and if they are to share a collective sense of responsibility, commitment, and ownership of the team's mission. A collective sense of empowerment is particularly important for virtual teams that meet infrequently. Thus, we predict:

Hypothesis 3. A team's number of face-to-face meetings will moderate the relationship be-

\footnotetext{
${ }^{1}$ We thank an anonymous reviewer for specific suggestions on developing the theoretical logic in this section.
}

tween team empowerment and process improvement; specifically, team empowerment will be more strongly related to process improvement in teams that meet less frequently face-to-face (that are higher in virtuality) than in teams that meet more frequently face-to-face (that are lower in virtuality).

Hypothesis 4. A team's number of face-to-face meetings will moderate the relationship between team empowerment and customer satisfaction; specifically, team empowerment will be more strongly related to customer satisfaction in teams that meet less frequently face-toface (that are higher in virtuality) than in teams that meet more frequently face-to-face (that are lower in virtuality).

\section{METHODS}

\section{Sample}

We conducted a field study to test the (1) direct effects of team empowerment on virtual team process improvement and customer satisfaction and (2) moderating effects of face-to-face interaction on the relationships between team empowerment and both process improvement and customer satisfaction. Specifically, we studied a high-technology service organization in the travel industry that had formally implemented virtual teams. The organization develops, installs, and services computer travel reservation systems for travel agencies and holds a majority ownership position in a company that offers Web-based travel services.

Each virtual team consisted of members with different roles, including account executives (selling the reservation systems), field service technicians (installing the systems), training representatives (training end users on the systems on-site), installation operation coordinators (setting up installation appointments), account management specialists (handling customer billing), and customer service representatives (fielding customer phone calls and questions).

Members of each team were geographically dispersed. Many members worked from offices in their homes. All of the day-to-day work carried out by teams was virtual in nature. Team members communicated using telephones and voice mail, e-mail, and instant messaging. Each team reported virtually to a general manager who had overall responsibility for monitoring team performance, supporting team training, and evaluating individual contributions to the team's objectives. Teams competed against each other on completion of training 
modules and on improvements in customer service indicators, among other criteria.

A total of 280 out of 333 team members responded to surveys representing 35 teams, giving us a response rate of 84 percent. In addition, for all 35 teams, more than half of the team members responded, which supported the use of the data at the team level of analysis. Sixty-nine percent of the respondents were female; 4 percent were less than 25 years old, 17 percent were 26-35 years old, 45 percent were $36-45,28$ percent were $46-55$, and 6 percent were over $55 ; 5$ percent were AfricanAmerican, 4 percent were Asian-American, 1 percent were Pacific Islanders, 12 percent were Hispanic-American, and 78 percent were Caucasian; 10.5 percent of the respondents had high school degrees or less, 12 percent had associate's degrees, 3.5 percent had technical degrees, 32 percent had some college beyond an associate's degree, 38.5 percent had bachelor's degrees, and 3.5 percent of the employees had graduate degrees. The average organizational tenure was 10.7 years, and the average team tenure was 2.4 years. There was an average of eight members per team.

\section{Measures}

Team empowerment. Team empowerment was assessed using a shortened version of Kirkman and Rosen's (1999) 26-item measure; the Appendix gives the 12 items used. These included 3 items representing each of the four team empowerment dimensions. Given high intercorrelations, the results of a principal components analysis, and a high level of fit using a one-factor confirmatory factor analysis, we combined our items into a single, global scale (e.g., Kirkman \& Rosen, 1999). Individual responses were aggregated to the team level of analysis. We tested the validity of aggregating team empowerment in several ways (Gibson, Randel, \& Earley, 2001; Kirkman, Tesluk, \& Rosen, 2001; Klein, Conn, Smith, \& Sorra, 2001; Tesluk, Zaccaro, Marks, \& Mathieu, 1997). First, we ran a one-way analysis of variance to ensure that the variance between teams was greater than the variance within teams, which was positively confirmed $\left(F_{34,244}=1.74, p<.01\right)$. Second, we used the interrater agreement procedure to assess reliability for each team (James, Demaree, \& Wolf, 1984, 1993). The mean interrater agreement $\left(r_{\mathrm{wg}}\right)$ across all teams for team empowerment was .95 (values ranged from .84 through .99), demonstrating very high within-group agreement. Third, we calculated the intraclass correlation coefficients, ICC(1) and ICC(2). The resulting ICC(1) of .10 indicated that a team membership accounted for a reasonable pro- portion of the variance in individual responses on team empowerment (James, 1982). Even though the ICC(1) value is not as high as might be desired, the ICC(2) value of .74 is large enough to indicate that the team means for empowerment were stable (Bliese, 2000). Thus, we treated team empowerment as a team-level construct in all of our subsequent analyses. The reliability for this scale was .93.

Process improvement. The participating organization used a sophisticated "balanced scorecard" that was administered at the team level (see Kaplan and Norton [1996] for a description of an organization-level balanced scorecard) to monitor each virtual team's performance. One independent component of the balanced scorecard was "process improvement," an assessment of reductions in cycle time for each team based on the number of days between an order for a travel reservation system and the effective operation of a system. Quarterly, the company's management set process improvement goals in number of days. Management calculated a process improvement percentage by dividing the number of days set by the goal by the number of actual days taken to complete an installation and then multiplying by 100 . Using this formula, higher process improvement percentages were better, and scores in our study ranged from a low of 112 percent to a high of 200 percent. Process improvement scores were available for all 35 virtual teams in our study, and we used scores calculated for the time period most closely following the completion of our survey. In this organization, which had been collecting process improvement data for two years prior to our data collection, process improvement was viewed as an objective assessment of team learning, or a team's ability to continually refine processes and develop innovative solutions to shorten the cycle time needed to deliver and install reservation systems. Our measure of process improvement is consistent with other recent subjective assessments of learning in teams, such as taking time to figure out ways to improve team work processes (Edmondson, 1999, 2002) and altering behavior on the basis of processing new information (Lynn, Skov, \& Abel, 1999).

Team customer satisfaction. A second component of the balanced scorecard was customer satisfaction. The company administered quarterly surveys to the outside customers (external to the organization) of each team. While answering several specific questions about customer service and support, customers also responded to a summary question, "What is your overall level of satisfaction with the service and support provided by this team?" (1, "not at all satisfied," to 5, "completely 
satisfied"). As with process improvement, the company set quarterly customer service goals for each team using the percentage of customer satisfaction ratings falling within the top two rating points (4, "somewhat satisfied," and 5, "completely satisfied"). Thus, for each team, management computed a customer satisfaction percentage by dividing the team's actual customer satisfaction percentage by the team's goal and then multiplying by 100 . For example, if a team had a goal of 90 percent customer satisfaction and then actually achieved a 90 percent score, that team's customer satisfaction percentage would be 100 percent $(90 / 90 \times 100)$. If, however, the team received an 80 percent score, its customer satisfaction percentage would be 89 percent $(80 / 90 \times 100)$. If the team received a 100 percent score, its percentage would be 111 percent $(100 / 90 \times 100)$. With this formula, higher customer satisfaction percentages are better, and scores in our study ranged from 71 to 119 percent. Rather than merely capturing percentages based on the raw scores of customer satisfaction, this measure thus relates actual customer satisfaction ratings to each team's customer satisfaction goal, which differed across teams depending on the complexity of the service provided and historical customer service ratings with that customer. As with process improvement, customer satisfaction percentages were available for all 35 of the virtual teams in our study and were collected for the time period most closely following our survey administration.

Number of face-to-face meetings. To assess the extent of teams' face-to-face interaction, we measured number of meetings with a single question on the team member survey: "How many times did your entire team meet face-to-face in the past year?" Each team member's response was aggregated to the team level. Number of team meetings in our sample ranged from 1 to 12 times per year, with a mean of 4.67 meetings per year. Checks for aggregating number of face-to-face team meetings yielded acceptable values $\left(F_{34,244}=2.16, p<.001\right.$; $\operatorname{ICC}[1]=.13$; ICC $[2]=.79)$. Management explained that even though all 35 teams performed the same task, the number of face-to-face meetings varied by team owing to factors such as team strategy, and team leader and member preferences. Number of team meetings was not significantly related to task characteristics such as task interdependence (Campion, Medsker, \& Higgs, 1993).

Control variables. Measures of control variables included team size, which was obtained from company records. Because task interdependence has been found to moderate the relationship between increased control in groups (autonomy) and team performance (Langfred, 2000; Liden, Wayne, \&
Bradway, 1997), we also measured and controlled for its potential moderating effect on the relationship between team empowerment and both process improvement and customer satisfaction. A threeitem task interdependence measure from Campion et al. (1993) was used. The reliability for this measure was .69, and checks for aggregating task interdependence yielded acceptable values $\left(F_{34,244}=\right.$ $\left.1.68, p<.05 ; r_{\mathrm{wg}}=.72 ; \operatorname{ICC}[1]=.10 ; \operatorname{ICC}[2]=.68\right)$.

\section{Procedures}

A total of 35 teams met our criteria for selection: (1) a minimum team life span of one year, (2) a clear team identity (teams had names, and clear boundaries existed between the teams), and (3) physical separation of team members. We contacted each team member via e-mail to explain the purpose and logistics of the survey and included an embedded Website link for completing the survey on-line. We told team members that their responses were confidential and anonymous, assured them that the data would be collected and maintained in an offsite computer system to help guarantee confidentiality, and explained that management would receive a summary report without individual identification.

\section{RESULTS}

Table 1 shows the means, standard deviations, and correlations. Hypotheses 1 and 2 were tested with hierarchical regression analysis. Table 2 presents the results of these tests. In step 1, we entered the control variables, and in step 2, team empowerment. As can been seen in the section of the table showing the values yielded by step 2, team empowerment was significantly, positively related to process improvement $(\beta=0.44, p<.01)$ and customer satisfaction ( $\beta=0.48, p<.01)$, a finding that supports Hypotheses 1 and 2.

To test Hypotheses 3 and 4, we used moderated regression analysis. In step 1, we entered all of the control variable "main effects" and both team empowerment and number of face-to-face team meetings. In step 2, we entered the interaction terms for both team empowerment and number of face-toface meetings, and team empowerment and task interdependence. Table 3 gives these results).

As can be seen in the step 2 results in Table 3, the interaction effect for team empowerment and faceto-face meetings was significant for process improvement $(\beta=-11.47, p<.01)$, supporting Hypothesis 3 , but it was not significant for customer service ( $\beta=0.45$, n.s.), failing to support Hypothesis 4 . The interaction effects for task interdepen- 
TABLE 1

Descriptive Statistics and Correlations ${ }^{\mathrm{a}}$

\begin{tabular}{|c|c|c|c|c|c|c|c|}
\hline Variable & Mean & s.d. & 1 & 2 & 3 & 4 & 5 \\
\hline 1. Team size & 8.00 & 2.83 & & & & & \\
\hline 2. Task interdependence & 5.61 & 0.45 & -.28 & & & & \\
\hline 3. Team empowerment & 5.46 & 0.53 & -.06 & .19 & & & \\
\hline 4. Number of face-to-face meetings & 4.67 & 2.61 & .05 & -.17 & .22 & & \\
\hline 5. Process improvement & 161.85 & 31.83 & -.02 & -.20 & $.39^{*}$ & .27 & \\
\hline 6. Team customer satisfaction & 95.25 & 8.76 & -.02 & -.10 & $.44^{* *}$ & -.06 & .12 \\
\hline
\end{tabular}

TABLE 2

Results of Hierarchical Regression Analysis ${ }^{a}$

\begin{tabular}{|c|c|c|c|c|c|c|c|c|}
\hline \multirow[b]{2}{*}{ Variable } & \multicolumn{4}{|c|}{95 Percent Confidence Interval } & \multicolumn{4}{|c|}{95 Percent Confidence Interval } \\
\hline & $\begin{array}{c}\text { Process } \\
\text { Improvement }\end{array}$ & $\begin{array}{l}\text { Lower } \\
\text { Bound }\end{array}$ & $\begin{array}{l}\text { Upper } \\
\text { Bound }\end{array}$ & Tolerance & $\begin{array}{l}\text { Customer } \\
\text { Satisfaction }\end{array}$ & $\begin{array}{l}\text { Lower } \\
\text { Bound }\end{array}$ & $\begin{array}{l}\text { Upper } \\
\text { Bound }\end{array}$ & Tolerance \\
\hline \multicolumn{9}{|l|}{ Step 1} \\
\hline Team size & -0.08 & -4.98 & 3.27 & 0.92 & -0.05 & -1.31 & 0.99 & 0.92 \\
\hline Task interdependence & -0.22 & -41.53 & 10.70 & 0.92 & -0.12 & -9.60 & 5.00 & 0.92 \\
\hline$F(d f)$ & \multicolumn{2}{|c|}{$0.73(2,32)$} & & & \multicolumn{2}{|c|}{$0.21(2,32)$} & & \\
\hline$R^{2}$ & \multirow{2}{*}{\multicolumn{2}{|c|}{$\begin{array}{r}.04 \\
-.02\end{array}$}} & & & \multirow{2}{*}{\multicolumn{2}{|c|}{$\begin{array}{r}.01 \\
-.05\end{array}$}} & & \\
\hline Adjusted $R^{2}$ & & & & & & & & \\
\hline \multicolumn{9}{|l|}{ Step 2} \\
\hline Team empowerment & $0.44^{* *}$ & 11.13 & 75.28 & 0.97 & $0.48^{* *}$ & 4.08 & 21.69 & 0.97 \\
\hline$F(d f)$ & \multicolumn{2}{|c|}{$3.10(3,31)$} & & & \multicolumn{2}{|c|}{$3.14 *(3,31)$} & & \\
\hline$R^{2}$ & \multicolumn{2}{|c|}{.23} & & & \multicolumn{2}{|c|}{$\begin{aligned} 0.14(0,01) \\
.23\end{aligned}$} & & \\
\hline Adjusted $R^{2}$ & \multicolumn{2}{|l|}{.16} & & & \multicolumn{2}{|l|}{.16} & & \\
\hline$\Delta R^{2 \mathrm{~b}}$ & \multicolumn{2}{|l|}{$.19^{* *}$} & & & \multicolumn{2}{|l|}{$.22^{* *}$} & & \\
\hline
\end{tabular}

a Standardized regression coefficients are shown.

b Step 1 to step 2 .

${ }^{*} p<.05$

${ }^{* *} p<.01$

dence as a control were not significant for either process improvement or customer satisfaction. Figure 2 shows the plot of the significant interaction (Aiken \& West, 1991). As can be seen in Figure 2, team empowerment was significantly, positively related to process improvement for teams that rarely met face-to-face (that is, teams that were higher in virtuality) and was not related to process improvement for teams that often met face-to-face (were lower in virtuality).

To ensure that we had included all appropriate control variables, we also ran additional post hoc analyses that included various indicators of team demographic heterogeneity, such as age, sex, race/ ethnicity, education, and organizational and team tenure. Previous research has shown effects for demographic heterogeneity on team outcomes (see Milliken and Martins [1996] and Williams and O'Reilly [1998] for reviews). We found no significant effects for the heterogeneity variables and thus do not report the results here. In addition, we examined the effects of team empowerment and the interaction of team empowerment and extent of face-to-face interaction on the raw scores for process improvement and customer satisfaction (that is, scores that did not take into account team goals set by the organization). We obtained highly similar results. Finally, we assured that none of the as- 
TABLE 3

Results of Moderated Regression Analysis ${ }^{\mathrm{a}}$

\begin{tabular}{|c|c|c|c|c|c|c|c|c|}
\hline \multirow[b]{2}{*}{ Variable } & \multicolumn{4}{|c|}{95 Percent Confidence Interval } & \multicolumn{4}{|c|}{95 Percent Confidence Interval } \\
\hline & $\begin{array}{c}\text { Process } \\
\text { Improvement }\end{array}$ & $\begin{array}{l}\text { Lower } \\
\text { Bound }\end{array}$ & $\begin{array}{l}\text { Upper } \\
\text { Bound }\end{array}$ & Tolerance & $\begin{array}{c}\text { Customer } \\
\text { Satisfaction }\end{array}$ & $\begin{array}{l}\text { Lower } \\
\text { Bound }\end{array}$ & $\begin{array}{l}\text { Upper } \\
\text { Bound }\end{array}$ & Tolerance \\
\hline \multicolumn{9}{|l|}{ Step 1} \\
\hline Team size & -0.07 & -4.61 & 2.96 & 0.92 & -0.05 & -1.16 & 0.88 & 0.92 \\
\hline Task interdependence & -0.27 & -43.99 & 5.79 & 0.86 & -0.25 & -11.67 & 1.77 & 0.86 \\
\hline$F(d f)$ & \multicolumn{4}{|c|}{$2.82^{*}(4,30)$} & \multicolumn{2}{|c|}{$2.90 *(4,30)$} & & \\
\hline$R^{2}$ & \multicolumn{2}{|l|}{.25} & & & \multicolumn{2}{|c|}{.28} & & \\
\hline Adjusted $R^{2}$ & \multicolumn{2}{|l|}{.15} & & & \multicolumn{2}{|l|}{.18} & & \\
\hline$F(d f)$ & \multicolumn{2}{|c|}{$3.30 *(6,28)$} & & & \multicolumn{2}{|c|}{$2.37(6,28)$} & & \\
\hline$R^{2}$ & \multicolumn{2}{|c|}{.41} & & & \multicolumn{2}{|c|}{.34} & & \\
\hline Adjusted $R^{2}$ & \multicolumn{2}{|l|}{.28} & & & \multicolumn{2}{|l|}{.20} & & \\
\hline$\Delta R^{2 \mathrm{~b}}$ & \multicolumn{2}{|l|}{$.16^{*}$} & & & \multicolumn{2}{|l|}{.06} & & \\
\hline
\end{tabular}

${ }^{\text {a }}$ Standardized regression coefficients are shown.

b Step 1 to step 2 .

${ }^{*} p<.05$

${ }^{* *} p<.01$

sumptions in our regression analyses were violated (for instance, skewness, kurtosis, and normality). We now turn to a discussion of the theoretical and managerial implications our findings.

\section{DISCUSSION}

In their article on temporal coordination and conflict management in virtual teams, MontoyaWeiss and her colleagues asked, "How can organizations create virtual teams that work effectively?" (2001: 1251). Because the literature on virtual teams is sparse, especially with regard to actual virtual teams performing meaningful tasks in organizations, the answer to this question has remained elusive. We believe that our study makes several contributions. First, we extend previous research on team empowerment by demonstrating the generalizability of the team empowermentteam performance relationship to virtual teams. Second, we demonstrate the importance of the extent of face-to-face interaction (an important component of degree of virtuality) and show its impact on antecedent-outcome relationships in virtual teams. Our findings suggest that virtual teams researchers need to take into account the extent of face-to-face interaction in studies of virtual team performance. Even when considering the same types of teams in the same organization, researchers may see variability in the degree of virtuality. Not all virtual teams are created alike. Finally, we extend previous research on virtual teams by examining team-level relationships in a set of service virtual teams in a meaningful organization setting, thus complementing existing virtual team studies using student samples or case methodology.

\section{Theoretical and Managerial Implications}

Empowerment and virtual team performance. Researchers have demonstrated positive links between team empowerment and colocated team performance in a variety of work settings (Burpitt \& Bigoness, 1997; Hyatt \& Ruddy, 1997; Kirkman \& Rosen, 1999; Wellins et al., 1991). Our findings showed team empowerment to be significantly, positively related to both process improvement and customer satisfaction in virtual teams. These find- 
FIGURE 2

The Moderating Effect of Number of Face-to-Face Meetings on the Relationship between Team Empowerment and Process Improvement

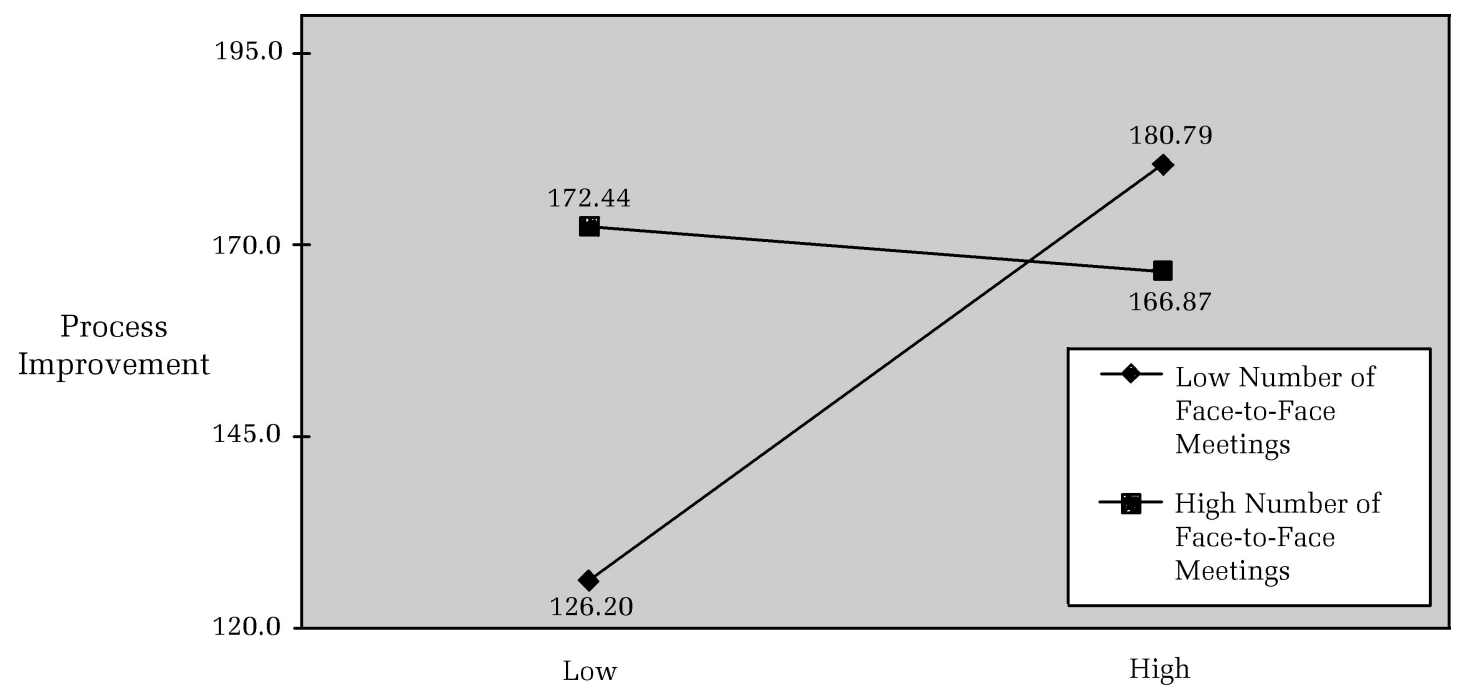

Team Empowerment

ings extend the previously established link between team empowerment and customer satisfaction in colocated teams (Kirkman \& Rosen, 1999). Our findings also support the multilevel role of empowerment in organizations (Seibert, Silver, \& Randolph, in press). At the individual level of analysis, empowerment has been positively linked to managerial performance, innovation, job satisfaction (Spreitzer, 1995; Spreitzer et al., 1997), and organizational commitment (Liden et al., 2000), and negatively linked to turnover intentions (Koberg et al., 1999). Our study supports the growing body of research suggesting that empowerment is a very important motivational construct at the team level of analysis as well. Researchers who build comprehensive models of virtual team effectiveness should include team empowerment as an important predictor variable.

Our results suggest that, for managers to enhance virtual team process improvement and customer satisfaction, they should increase team empowerment. In virtual teams, team members must demonstrate a particularly high level of initiative and proactivity (Blackburn, Furst, \& Rosen, 2003; Duarte \& Snyder, 2001; Haywood, 1998; Lipnack \& Stamps, 2000; Townsend et al., 1998). Accordingly, it is important that team members collectively feel enabled to improve processes and respond to changing customer demands, often coming up with creative solutions to resolve problems and emergency situations. Researchers have recommended ways to increase team empowerment in colocated teams (Kirkman \& Rosen, 1999); however, there may be important differences in the empowerment of colocated and virtual teams.

For example, to empower colocated teams, researchers have recommended that team leaders encourage teams to solve their own problems and set high expectations (Kirkman \& Rosen, 1999). In view of the dispersed nature of virtual teams, team leaders will likely have to spend considerable time coaching individual team members off-line and work diligently to ensure that all team members feel fully informed about important organizational matters and events (Kayworth \& Leidner, 2001; Kirkman et al., 2002). Encouraging team problem solving and setting high expectations may have little impact in virtual teams if team members do not clearly see how their efforts contribute to team and organizational performance, which is more problematic for dispersed, rather than colocated, members. Similarly, researchers have suggested that modifying social structures to establish more communication and coordination across teams is important to empower colocated teams (Kirkman \& Rosen, 1999). However, in virtual teams, since almost all communication and coordination occur through electronic media, teams will have to be trained on using such technology, and members will need excellent technical support from management and knowledge about when to use which technology (Townsend et al., 1998). We expect that the empowerment of virtual teams will be much more complex than that of colocated teams (Kayworth \& 
Leidner, 2001). Much future research is required in this area before clear mechanisms for empowering virtual teams emerge.

Face-to-face interaction and virtual team performance. Our second objective was to examine whether the number of face-to-face team meetings moderated the relationship between team empowerment and team performance. We believed that team empowerment would be more important for teams that met less, rather than more, frequently. Supporting our expectation, we found that virtuality, as assessed by number of face-to-face team meetings, moderated the relationship between team empowerment and one dimension of virtual team performance-process improvement. Among teams that rarely meet face-to-face (highly virtual teams), it appears that team empowerment experiences are critical for learning to occur in teams. As shown in Figure 2, there is a dramatic contrast between the level of process improvement achieved by highly empowered (one standard deviation above the mean) teams that rarely meet face-to-face $(\bar{x}=180.79)$ and the process improvement achieved by less empowered (one standard deviation below the mean) teams that rarely meet face-to-face $(\bar{x}=126.20)$. When teams seldom interact face-to-face, it appears that process improvement is contingent on team empowerment experiences. Empowered teams may view themselves as capable of responding to the challenges of slow cycle times and confident in their abilities to act quickly and decisively to remove obstacles and solve complex coordination problems without waiting for managerial approval (Kirkman \& Rosen, 1997).

In contrast, teams that lack empowerment and rarely meet face-to-face may become passive and likely to rely on their leaders for direction as to how to address continual improvement objectives. Because team leaders manage their teams through largely virtual means and rely on less rich communication, it is more difficult to encourage teams that feel less empowered to concentrate their energies on addressing process improvement goals (Bell \& Kozlowski, 2002). Moreover, less empowered virtual teams that seldom meet face-to-face may overestimate perceived constraints around taking corrective actions. One interpretation of these findings is that teams that rarely meet face-to-face require a collective sense of empowerment in order to learn and make meaningful process improvements. For teams that hold frequent face-to-face meetings (those low in virtuality), levels of team empowerment were not related to process improvement. This finding contrasts with earlier research that showed strong links between team empowerment and performance (Burpitt \& Bigoness, 1997; Hyatt \& Ruddy, 1997; Kirkman \& Rosen, 1999). The conflicting findings may be the result of differences in the way team performance was measured or the types of teams studied. For example, none of the previous studies measured team learning as evidenced by process improvement. Or perhaps faceto-face meetings encourage the development of cohesion, consensus, and mutual accountability that enhance efforts to improve processes regardless of the level of empowerment (or, in effect, substituting for empowerment). Another explanation may be the role of leaders in low-empowerment virtual teams that meet frequently. Here leaders may adopt a more directive style, focusing team members' collective attention on the need for process improvement. An interesting question, deserving of further investigation, is whether leaders call for more faceto-face meetings and act more assertively when teams show little initiative in addressing process improvement issues. Clearly, future research is needed to determine causality over time.

Regarding theory, researchers have questioned how virtuality affects virtual team performance (Bell \& Kozlowski, 2002; Gibson \& Cohen, 2003; Griffith \& Neale, 2001; Griffith et al., 2003). To date, however, very little empirical research has answered this call. Although we recognize the more complex, multidimensional definitions of the construct, we believe that our research takes a first step in the empirical evolution of this important variable. Realizing that substantial variance exists with respect to degree of virtuality among virtual teams within and across real organizations, the conceptualization, measurement, and assessment of virtuality should help advance virtual team theory and research. Inclusion of degree of virtuality also indirectly supports our earlier claim that, while team empowerment has been shown to be important for colocated teams, it is even more important for virtual teams. For example, while all of the teams in our study were considered virtual owing to the lack of face-to-face interaction in carrying out day-today work, we found that empowerment was more important to teams that rarely met than for teams that met more frequently. Comparative research including both highly face-to-face and highly virtual teams (e.g., Potter \& Balthazard, 2002) is now needed to more directly assess the assertion that team empowerment is more important for virtual rather than for colocated teams.

Inclusion of assessments of virtuality, such as the extent of face-to-face interaction, as part of the design of any research project on virtual teams, has the added benefit of facilitating a comparison of findings from research across a variety of virtual 
team settings. A parallel situation exists with regard to the research on self-managing work teams (SMWTs). When researchers fail to include a measure of the degree of self-management, comparisons across studies are difficult. Thus, SMWT research has remained disjointed and unable to capitalize on a systematic, cumulative base of knowledge (Guzzo \& Dickson, 1996).

The findings for team empowerment and the extent of face-to-face interaction in virtual teams also have implications for managers. First, our findings may assist leaders of virtual teams in determining the number of face-to-face team meetings that is appropriate to the level of team empowerment. Specifically, when teams experience little empowerment, frequent face-to-face meetings appear critical to learning (see Figure 2). Second, some managers may find that they have very little control over the number of faceto-face meetings they can arrange. Often, virtual teams are formed because members simply cannot meet face-to-face. If managers have very little control over face-to-face meeting frequency, because of dispersion of members or resource constraints, they need to focus their team-building efforts on increasing team empowerment. Indeed, the organization that served as the setting for this study encouraged its team leaders to take advantage of limited opportunities for their teams to meet face-to-face to engage in activities and exercises to build team identity, confidence in team capabilities, and a collective sense of purpose and direction (a sense of empowerment).

Although we found that number of face-to-face meetings had a significant, moderating effect on the relationship between team empowerment and process improvement, we did not find this effect for customer satisfaction. Thus, more empowered teams were better able to satisfy their customers than less empowered teams regardless of the number of times the teams assembled face-to-face. Perhaps team members better understood the actions needed to satisfy customers (such as quick installations, corrections of billing problems, training in the use of software), and thus face-to-face team meetings were not as critical to increase customer service. In contrast, regarding process improvement, for teams that met frequently, the level of empowerment was irrelevant. Risk taking, experimentation, and reflection-all actions that are critical for team learning (Edmondson, 1999; 2002)— most likely occurred in face-to-face meetings as teams worked on reducing cycle time. However, for those that rarely met, team empowerment had a dramatic effect on learning. Apparently, empowerment is needed under these conditions because team members must have the authority to engage in activities such as experimentation without the managerial guidance common in most face-to-face meetings.

\section{Limitations and Future Research}

Our first limitation is the number of teams in the study. This limitation is offset to some extent by our having used a sample of virtual teams performing the same task and assessed by two independent outcome measures in a business organization. Such a sample is relatively rare in field research. In addition, given that it is difficult to obtain field samples with high numbers of teams, our study is in line with existing studies in both face-to-face team research (Ancona \& Caldwell, 1992; Janz, Colquitt, \& Noe, 1997; Pelled, Eisenhardt, \& Xin, 1999) and virtual team studies (Jarvenpaa et al., 1998; Montoya-Weiss et al., 2001; Warkentin et al., 1997).

A second limitation is our unidimensional representation of virtuality. Measuring number of faceto-face meetings may have failed to capture the quality of virtual team meetings as well as other dimensions, such as physical dispersion, richness of communication media, and number of time zones crossed. As we noted, we encourage future researchers to build on our conceptualization to explore possible multidimensional aspects and measures of degree of virtuality.

A third limitation of our study is its crosssectional design. Thus, we were unable to conclusively demonstrate that higher levels of team empowerment led to enhanced process improvement and customer satisfaction. It may be the case that higher levels of learning and customer satisfaction cause team members to feel more empowered. As has been argued about empowerment and performance at the individual level (e.g., Spreitzer, 1995), team empowerment and team performance are likely to have a reciprocal relationship (Kirkman \& Rosen, 1999) that is similar to an efficacy spiral (Lindsley, Brass, \& Thomas, 1995). Clearly, longitudinal studies are needed. On a positive note, we were able to capture timely assessments of team empowerment using an on-line survey. Team empowerment was compared to current indicators of team performance collected after our survey was administered.

A final limitation is the number of variables we were able to include in our study. Clearly, the lack of existing research on virtual teams warrants the assessment of a comprehensive model of virtual team performance. Most important may be the inclusion of process variables such as communica- 
tion, decision making, and conflict management that might help to explain process improvement or customer satisfaction. We chose to take a more limited approach because of restrictions on our degrees of freedom, given 35 teams, and organizational concerns over survey length. We strongly encourage future researchers to find and examine larger samples of virtual teams performing real tasks in actual organizations.

\section{Conclusion}

To our knowledge, this study is the first to examine the influence of team empowerment on virtual team performance using intact virtual teams performing meaningful tasks in an actual business organization. In addition, we proposed and explored an important element of degree of virtuality (Bell \& Kozlowski, 2002; Cohen \& Gibson, 2003; Griffeth \& Neale, 2001; Griffeth et al., 2003)—number of face-to-face team meetings-and examined its moderating effects on the relationship between empowerment and two independent measures of virtual team performance. We hope our findings contribute to further theoretical and empirical development of the degree of virtuality construct and to a more comprehensive model of virtual team performance.

Our findings have several important implications for leading and managing virtual teams. Highly empowered virtual teams were associated with significantly higher levels of process improvement and customer satisfaction than were less empowered teams. Moreover, high levels of team empowerment were critical to process improvement for teams that rarely met face-to-face. To enhance the effectiveness of virtual teams, managers have several options. One option is to bring virtual teams together for periodic face-toface meetings to enhance process improvement. Where periodic face-to-face meetings are not feasible, managers need to make extra efforts to empower virtual teams to deal directly and decisively with process improvement issues. With the growing popularity of virtual teams, both comprehensive models of virtual team effectiveness and rigorous longitudinal studies of virtual team performance are clearly needed.

\section{REFERENCES}

Aiken, L. S., \& West, S. G. 1991. Multiple regression: Testing and interpreting interactions. Newbury Park, CA: Sage.

Ancona, D. G., \& Caldwell, D. F. 1992. Demography and design: Predictors of new product team performance. Organization Science, 3: 321-341.
Armstrong, D. J., \& Cole, P. 1995. Managing distances and differences in geographically distributed work groups. In S. E. Jackson \& M. N. Ruderman (Eds.), Diversity in work teams: Research paradigms for a changing workplace: 187-215. Washington, DC: American Psychological Association.

Bell, B. S., \& Kozlowski, S. W. J. 2002. A typology of virtual teams: Implications for effective leadership. Group \& Organization Management, 27: 14-49.

Blackburn, R. S., Furst, S. A., \& Rosen, B. 2003. Building a winning virtual team. In C. B. Gibson \& S. G. Cohen (Eds.), Virtual teams that work: Creating the conditions for virtual team effectiveness: 95-120. San Francisco: Jossey-Bass.

Bliese, P. D. 2000. Within-group agreement, non-independence, and reliability: Implications for data aggregation and analysis. In K. J. Klein \& S. W. J. Kozlowski (Eds.), Multilevel theory, research and methods in organizations: $349-381$. San Francisco: Jossey-Bass.

Burpitt, W. J., \& Bigoness, W. J. 1997. Leadership and innovation among teams: The impact of empowerment. Small Group Research, 28: 414-423.

Campion, M. A., Medsker, G. J., \& Higgs, A. C. 1993. Relations between work group characteristics and effectiveness: Implications for designing effective work groups. Personnel Psychology, 46: 823-850.

Cascio, W. F. 2000. Managing a virtual workplace. Academy of Management Executive, 14(3): 81-90.

Champy, J., \& Nohria, N. 1997. Fast forward: The best ideas on managing business change. Boston: Harvard Business School Press.

Chan, D. 1998. Functional relations among constructs in the same content domain at different level of analysis: A typology of composition models. Journal of Applied Psychology, 83: 234-246.

Cohen, S. G., \& Bailey, D. E. 1997. What makes teams work: Group effectiveness research from the shop floor to the executive suite. Journal of Management, 23: $239-290$.

Cohen, S. G., \& Gibson, C. B. 2003. In the beginning: Introduction and framework. In C. B. Gibson \& S. G. Cohen (Eds.), Virtual teams that work: Creating conditions for virtual team effectiveness: $1-13$. San Francisco: Jossey-Bass.

Conger, J. A., \& Kanungo, R. N. 1988. The empowerment process: Integrating theory and practice. Academy of Management Review, 13: 471-482.

Coutu, D. L. 1998. Trust in virtual teams. Harvard Business Review, 76(3): 20-21.

Crant, J. M. 2000. Proactive behavior in organizations. Journal of Management, 26: 435-462.

Deci, E. L., \& Ryan, R. M. 1980. The empirical exploration of intrinsic motivational processes. In L. Berkowitz (Ed.), Advances in experimental social psychology, vol. 13: 39-80. New York: Academic Press. 
Duarte, D. L., \& Snyder, N. T. 2001. Mastering virtual teams (2nd ed.). San Francisco: Jossey-Bass.

Edmondson, A. 1999. Psychological safety and learning behavior in work teams. Administrative Science Quarterly, 44: 350-383.

Edmondson, A. 2002. The local and variegated nature of learning in organizations: A group-level perspective. Organization Science, 13: 128-146.

Edmondson, A., Bohmer, R. M., \& Pisano, G. P. 2001. Disrupted routines: Team learning and new technology implementation in hospitals. Administrative Science Quarterly, 46: 685-716.

Ford, R. C., \& Fottler, M. D. 1995. Empowerment: A matter of degree. Academy of Management Executive, 9(3): 21-31.

Furst, S. A., Blackburn, R. S., \& Rosen, B. 1999. Virtual team effectiveness: A proposed research agenda. Information Systems Journal, 9: 249-269.

Geber, B. 1995. Virtual teams. Training, 32(4): 36-40.

Gibson, C. B. 2001. From accumulation to accommodation: The chemistry of collective cognition in work groups. Journal of Organizational Behavior, 22: 121-134.

Gibson, C. B., \& Cohen, S. G. 2003. The last word: Conclusions and implications. In C. B. Gibson \& S. G. Cohen (Eds.), Virtual teams that work: Creating conditions for virtual team effectiveness: 403-421. San Francisco: Jossey-Bass.

Gibson, C. B., \& Randel, A. E., \& Earley, P. C. 2000. Understanding group-efficacy: An empirical test of multiple assessment methods. Group \& Organization Management, 25: 67-97.

Gluesing, J. C., Alcordo, T. C., Baba, M. L., Britt, D., Wagner, K. H., McKether, W., Monplaisir, L., Ratner, H. H., \& Rioppelle, K. 2003. The development of global virtual teams. In C. B. Gibson \& S. G. Cohen (Eds.), Virtual teams that work: Creating conditions for virtual team effectiveness: $353-380$. San Francisco: Jossey-Bass.

Gorn, G. J., \& Kanungo, R. N. 1980. Job involvement and motivation: Are intrinsically motivated managers more job involved? Organizational Behavior and Human Performance, 26: 265-277.

Griffith, T. L., \& Neale, M. A. 2001. Information processing in traditional, hybrid, and virtual teams: From nascent knowledge to transactive memory. Research in organizational behavior, vol. 23: 379421. Greenwich, CT: JAI Press.

Griffith, T. L., Sawyer, J. E., \& Neale, M. A. 2003. Virtualness and knowledge in teams: Managing the love triangle of organizations, individuals, and information technology. MIS Quarterly, 27: 265287.

Guzzo, R. A., \& Dickson, R. A. 1996. Teams in organizations: Recent research on performance and effectiveness. In L. W. Porter (Ed.), Annual review of psy- chology, vol. 47: 307-338. Palo Alto, CA: Annual Reviews.

Guzzo, R. A., Campbell, R. J., Moses, J. L., Ritchie, R. R., Schneider, B., Shaff, K., Wheeler, J., Gufstason, P. W. 1991. What makes high-performing teams effective? Unpublished manuscript, University of Maryland, College Park, Maryland.

Hackman, J. R. 1987. The design of work teams. In J. Lorsch (Ed.), Handbook of organizational behavior: 315-342. Englewood Cliffs, NJ: Prentice-Hall.

Hackman, J. R., \& Oldham, G. R. 1980. Work redesign. Reading, MA: Addison-Wesley.

Haywood, M. 1998. Managing virtual teams: Practical techniques for high-technology managers. Boston: Artech House.

Hyatt, D. E., \& Ruddy, T. M. 1997. An examination of the relationship between work group characteristics and performance: Once more into the breech. Personnel Psychology, 50: 553-585.

James, L. R. 1982. Aggregation bias in estimates of perceptual agreement. Journal of Applied Psychology, 67: 219-229.

James, L. R., Demaree, R. G., \& Wolf, G. 1984. Estimating within-group interrater reliability with and without response bias. Journal of Applied Psychology, 69: 85-98.

James, L. R., Demaree, R. G., \& Wolf, G. 1993. $\mathrm{r}_{\mathrm{wg}}$ : An assessment of within-group interrater agreement. Journal of Applied Psychology, 78: 306-309.

Janz, B. D., Colquitt, J. A., \& Noe, R. A. 1997. Knowledge worker team effectiveness: The role of autonomy, interdependence, team development, and contextual support variables. Personnel Psychology, 50: 877904.

Jarvenpaa, S. L., \& Leidner, D. E. 1999. Communication and trust in global virtual teams. Organization Science, 10: 791-815.

Jarvenpaa, S. L., Knoll, K., \& Leidner, D. E. 1998. Is anybody out there? Antecedents of trust in global virtual teams. Journal of Management Information Systems, 14: 29-64.

Kaplan, R. S., \& Norton, D. P. 1996. Using the balanced scorecard as a strategic management system. Harvard Business Review, 74(1): 75-85.

Kayworth, T. R., \& Leidner, D. E. 2001. Leadership effectiveness in global virtual teams. Journal of Management Information Systems, 18: 7-40.

Kerr, S., \& Jermier, J. M. 1978. Substitutes for leadership: Their meaning and measurement. Organizational Behavior and Human Performance, 22: 375-403.

King, N., \& Majchzrak, A. 2003. Technology alignment and adaptation for virtual teams involved in unstructured knowledge work. In C. B. Gibson \& S. G. Cohen (Eds.), Virtual teams that work: Creating condi- 
tions for virtual team effectiveness: 265-291. San Francisco: Jossey-Bass.

Kirkman, B. L., \& Rosen, B. 1997. A model of work team empowerment. In R. W. Woodman \& W. A. Pasmore (Eds.), Research in organizational change and development, vol. 10: 131-167. Greenwich, CT: JAI Press.

Kirkman, B. L., \& Rosen, B. 1999. Beyond self-management: The antecedents and consequences of team empowerment. Academy of Management Journal, 42: 58-74.

Kirkman, B. L., \& Rosen, B. 2000. Powering up teams. Organizational Dynamics, 28(3): 48-66.

Kirkman, B. L., Rosen, B., Gibson, C. B., Tesluk, P. E., \& McPherson, S. O. 2002. Five challenges to virtual team success: Lessons from Sabre, Inc. Academy of Management Executive, 16(3): 67-79.

Kirkman, B. L., Tesluk, P. E., \& Rosen, B. 2001. Assessing the incremental validity of team consensus ratings over aggregation of individual-level data in predicting team effectiveness. Personnel Psychology, 54: 645-667.

Klein, K. J., Conn, A. L., Smith, D. B., \& Sorra, J. S. 2001. Is everyone in agreement? Exploring the determinants of within-group agreement in survey responses. Journal of Applied Psychology, 86: 3-16.

Koberg, C. S., Boss, R. W., Senjem, J. C., \& Goodman, E. A. 1999. Antecedents and outcomes of empowerment: Empirical evidence from the health care industry. Group \& Organization Management, 24: 71-91.

Kristof, A. L., Brown, K. G., Sims, H. P., \& Smith, K. A. 1995. The virtual team: A case study and inductive model. In M. M. Beyerlein, D. A. Johnson, \& S. T. Beyerlein (Eds.), Advances in interdisciplinary studies of work teams: Knowledge work in teams, vol. 2: 229-253. Greenwich, CT: JAI Press.

Langfred, C. W. 2000. Work-group design and autonomy: A field study of the interaction between task interdependence and group autonomy. Small Group Research, 31: 54-70.

Liden, R. C., Wayne, S. J., \& Sparrowe, R. T. 2000. An examination of the mediating role of psychological empowerment on the relations between the job, interpersonal relationships, and work outcomes. Journal of Applied Psychology, 85: 407-416.

Liden, R. C., Wayne, S. J., \& Bradway, L. K. 1997. Task interdependence as a moderator of the relation between group control and performance. Human Relations, 50: 169-181.

Lindsley, D. H., Brass, D. J., \& Thomas, J. B. 1995. Efficacy-performance spirals: A multilevel perspective. Academy of Management Review, 3: 645-678.

Lipnack, J., \& Stamps, J. 1999. Virtual teams: The new way to work. Strategy \& Leadership, 27(1): 14-19.
Lipnack, J., \& Stamps, J. 2000. Virtual teams: People working across boundaries with technology (2nd ed.). New York: Wiley.

Lynn, G. S., Skov, R. B., \& Abel, K. D. 1999. Practices that support team learning and their impact on speed to market and new product success. Journal of Product Innovation Management, 16: 439-454.

Marks, M. A., Mathieu, J. E., \& Zaccaro, S. J. 2001. A temporally based framework and taxonomy of team processes. Academy of Management Review, 26: 356-376.

Maznevski, M. L., \& Chudoba, K. M. 2000. Bridging space over time: Global virtual-team dynamics and effectiveness. Organization Science, 11: 473-492.

Maznevski, M. L., \& Athanassiou, N. A. 2003. Designing the knowledge-management infrastructure for virtual teams: Building and using social networks and social capital. In C. B. Gibson \& S. G. Cohen (Eds.), Virtual teams that work: Creating conditions for virtual team effectiveness: 196-213. San Francisco: Jossey-Bass.

Milliken, F. J., \& Martins, L. L. 1996. Searching for common threads: Understanding the multiple effects of diversity in organizational groups. Academy of Management Review, 21: 402-433.

Mohrman, S. A., Cohen, S. G., \& Mohrman, A. M. 1995. Designing team-based organizations: New forms for knowledge work. San Francisco: Jossey-Bass.

Montoya-Weiss, M. M., Massey, A. P., \& Song, M. 2001. Getting it together: Temporal coordination and conflict management in global virtual teams. Academy of Management Journal, 44: 1251-1262.

Pelled, L. H., Eisenhardt, K. M., \& Xin, K. R. 1999. Exploring the black box: An analysis of work group diversity, conflict, and performance. Administrative Science Quarterly, 44: 1-28.

Potter, R. E., \& Balthazard, P. A. 2002. Understanding human interaction and performance in the virtual team. Journal of Information Technology Theory and Application, 4(1): 1-23.

Raven, A. 2003. Team or community of practiceAligning tasks, structures, and technologies. In C. B. Gibson \& S. G. Cohen (Eds.), Virtual teams that work: Creating conditions for virtual team effectiveness: 292-306. San Francisco: JosseyBass.

Redding, J. C. 2000. The radical team handbook: Harnessing the power of team learning for breakthrough results. San Francisco: Jossey-Bass.

Seibert, S. E., Silver, S. R., \& Randolph, W. A. 2004. Taking empowerment to the next level: A multilevel model of empowerment, performance, and satisfaction. Academy of Management Journal, 47: In press.

Shea, G. P., \& Guzzo, R. A. 1987. Group effectiveness: What really matters? Sloan Management Review, 28(3): 25-31. 
Spreitzer, G. M. 1995. Psychological empowerment in the workplace: Dimensions, measurement, and validation. Academy of Management Journal, 38: 1442-1465.

Spreitzer, G. M. 1996. Social structural characteristics of psychological empowerment. Academy of Management Journal, 39: 483-504.

Spreitzer, G. M., Kizilos, M. A., \& Nason, S. W. 1997. A dimensional analysis of the relationship between psychological empowerment and effectiveness, satisfaction, and strain. Journal of Management, 23: $679-704$.

Tesluk, P. E., Zaccaro, S. J., Marks, M. A., \& Mathieu, J. E. 1997. Task and aggregation issues in the analysis and assessment of team performance. In M. T. Brannick \& E. Salas (Eds.), Assessment and measurement of team performance: Theory, research and applications: 197-224. Greenwich, CT: JAI Press.

Thomas, K. W., \& Velthouse, B. A. 1990. Cognitive elements of empowerment: An "interpretive" model of intrinsic task motivation. Academy of Management Review, 15: 666-681.

Townsend, A. M., DeMarie, S. M., \& Hendrickson, A. R. 1998. Virtual teams: Technology and the workplace of the future. Academy of Management Executive, 12(3): 17-29.

Tushman, M. L., \& O’Reilly, C. A., III. 1996. Ambidextrous organizations: Managing evolutionary and revolutionary change. California Management Review, 38(4): $8-30$.

Warkentin, M. E., Sayeed, L., \& Hightower, R. 1997. Virtual teams versus face-to-face teams: An exploratory study of a web-based conference system. Decision Sciences, 28: 975-996.

Watkins, K. E., \& Marsick, V. J. 1993. Sculpting the learning organization. San Francisco: Jossey-Bass.

Wellins, R. S., Byham, W. C., \& Wilson, J. M. 1991. Empowered teams: Creating self-directed work groups that improve quality, productivity, and participation. San Francisco: Jossey-Bass.

Williams, K. Y., \& O’Reilly, C. A., III. 1998. Demography and diversity in organizations: A review of 40 years of research. In B. M. Staw \& L. L. Cummings (Eds.), Research in organizational behavior, vol. 20: 77140. Greenwich, CT: JAI Press.

\section{APPENDIX}

\section{Survey Items Used in the Study}

Team Empowerment

This scale is a shortened version of Kirkman and Rosen's (1999) 26-item original. Response options ranged from 1, "strongly disagree," to 7, "strongly agree." The dimensions of empowerment tapped by items appear here, in parentheses, but were not included in the survey as administered to respondents.
1. My team has confidence in itself. (potency)

2. My team can get a lot done when it works hard. (potency)

3. My team believes that it can be very productive. (potency)

4. My team believes that its projects are significant. (meaningfulness)

5. My team feels that its tasks are worthwhile. (meaningfulness)

6. My team feels that its work is meaningful. (meaningfulness)

7. My team can select different ways to do the team's work. (autonomy)

8. My team determines as a team how things are done in the team. (autonomy)

9. My team makes its own choices without being told by management. (autonomy)

10. My team has a positive impact on this company's customers. (impact)

11. My team performs tasks that matter to this company. (impact)

12. My team makes a difference in this organization. (impact)

Task Interdependence Campion, Medsker, and Higgs (1993) developed this measure.

1. My team cannot accomplish its tasks without information or materials from other members of the team.

2. Members of my team depend on each other for information or materials needed to perform their tasks.

3. Within my team, jobs performed by team members are all related to one another.

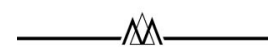

Bradley L. Kirkman (brad.kirkman@mgt.gatech.edu) is associate professor of management in the College of Management at the Georgia Institute of Technology. He received his Ph.D. in organizational behavior from the Kenan-Flagler Business School at the University of North Carolina at Chapel Hill. His research interests include work team effectiveness, cross-cultural management, organizational change and development, and organizational justice.

Benson Rosen is the Hanes Professor of Management in the Kenan-Flagler Business School at the University of North Carolina at Chapel Hill. He received his Ph.D. in social and industrial psychology from Wayne State University. His research interests include team development, career management, and international ethics.

Paul E. Tesluk is an associate professor of organizational behavior at the University of Maryland and Associate Director of the Center for Human Capital, Innovation and Technology at the Robert H. Smith School of Business. He received his Ph.D. from the 
Pennsylvania State University in industrial/organizational psychology. His research interests include the design and implementation of high-involvement workplace systems, work team performance, and employee and managerial development.

Cristina B. Gibson is an assistant professor at the Graduate School of Management, University of California,
Irvine, where she received her Ph.D. in organizational behavior. Her research interests include social cognition, communication, interaction, and effectiveness in teams; the impact of culture and gender on work behavior; and international management.

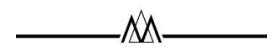

